\title{
ANALISIS MOM AND POP STORE DI KOTA BATAM HINGGA TAHUN 2018
}

\author{
Tiurniari Purba \\ Dosen Program Studi Manajemen, Universitas Putera Batam \\ email: tiurniari@gmail.com
}

\begin{abstract}
Non-minimarket traders and convenience stores are getting weaker along with the presence of modern retailers. Non-minimarket traders are also called traders at mom and pop or mom and pop stores. This case happened not only in other cities or other countries, but also in Batam. The presence of modern retailers, especially retail Indomaret and Alfamart retail in Batam, gave a lot of changes to the mom and pop store. This article aims specifically of analyzing the situation faced by mom and pop stores in Batam after the presence of modern retailers, especially Indomaret and Alfamart. And to what extent does the influence of the presence of Indomaret and Alfamart affect shops and stalls in Batam City? The research methodology used to analyze is a type of qualitative research with a case study approach to the type of situation analysis. The type of case study of this study is trying to analyze the situation of a particular event or event. External situation analysis is a systematic review of the background of problems that are outside the organization. Types of external situation analysis include secondary data (literature studies), surveys, observations, and content analysis. From the results of the analysis it was found that the presence of modern retailers until 2018 cannot be rejected and resisted by those who have a direct interest because access through the government of a wide open city. As a result, hundreds of modern retailers, especially Indomaret retail and Alfamart retail, have been established in Batam city. The mom and pop store has been eliminated, ranging from four to five mom and pop stores that broke up and closed in every housing complex. The hope for the mom and pop store owners that still persists up to now is the government's interference with the quota limit on the number of modern retailers. Also the involvement of the government both financially and ideas to foster the community about healthy ways to compete in the market.
\end{abstract}

Keywords: Retail modern, Mom and pop, Store

\section{PENDAHULUAN}

Dalam jarak dan radius yang yang dekat, sangat mudah ditemukan keberadaan ritel modern terutama ritel Indomaret dan Alfamart. Tidak dapat dipungkiri dengan hanya klik google map, ritel Indomaret dan Alfamart berjumlah ratusan. Sejak masuknya kedua jenis ritel ini ke Batam yaitu tahun 2014 hingga tahun 2018 jumlahnya sudah mencapai ratusan. Bahkan di tahun 2018 jenis ritel Indomaret mempunyai target 1000 unit gerai harus dibuka di Indonesia. Di Sembilan kecamatan dari 12 kecamatan yang ada di Batam, berdiri dimana mana yang namanya ritel indomaret dan Alfamart. Kedua jenis ritel ini semakin menenggelamkan keberadaan jenis mom and pop store. Tidak ada batasan dari segi jarak dalam realitanya antar ritel modern dengan mom $n$ pop strore yang ada bahkan yang sudah ada sebelumnya. Sementara jarak sangat menpengaruhi keberlangsungan hidup sebuah mom and pop store kalau disaingi oleh ritel modern (Giovanni \& Tadei, 2014). Mom an Pop store is a small, independent, usually family-owned, controlled, and operated business that has a minimum amount of employees, has only a small amount of business volume, and is typically not franchised, therefore open for business only in a single location. http://www.businessdictionary.com

Genjatan pertumbuhan juhlah kedua ritel ini memaksa pemerintah Kota Batam untuk membatasi jumlah kuota, tapi dengan motif bisnis batasan kuota tidak seketat tertulis. Ritel bernama Indomaret dan Alfamart tidak lagi hanya berjumlah satu dua atau puluhan di Kota Batam melainkan ratusan dan hingga tahun 2018 masih tetap bertambah. Di era ekonomi 
modern sekarang ini, bisnis di sektor ritel sangat sukses besar (Singh, 2014). Ritel modern adalah penataan barang menurut keperluan yang sama dikelompokkan di bagian yang sama yang dapat dilihat dan diambil langsung oleh pembeli, penggunaan alat pendingin udara, dan adanya pramuniaga profesional (Ma'ruf, 2005).

Dalam jangka waktu yang sangat singkat kedua ritel modern tersebut menjamur di setiap sudut kota Batam. Kedua ritel ini mampu mencuri perilaku konsumen dari yang sebelumnya pembeli di warung, toko, dan pasar, menjadi beli di minimarket. Perubahan perilaku ini hari demi hari ditandai dengan tingkah laku kecenderungan konsumen yang memilih berbelanja di ritel modern dibandingkan ritel tradisional sehingga berpengaruh terhadap menurunnya transaksi di ritel tradisional, terjadi pengurangan market share. Kelihaian memahami ritel modern dari aspek kepuasan konsumen terhadap pelayanan toko, visual toko, fasilitas yang diberikan toko dan juga mengenai harga pada ritel modern semakin semakin menyusutkan keberadaan saingannya (Utomo, 2011).

Dengan berkaca pada perilaku konsumen, kedua ritel ini menjadi sangat booming di Indonesia kecuali di beberapa tempat seperti di Sumatera Barat. Kedua ritel ini sedang merangkak memasuki pasar internasional dan bahkan sudah ada di beberapa negara seperti; Filipina, Afrika, dan negara lainnya. Bahkan Alfamart menjadi brand ritel nomor satu di Filipina. Ritel inilah salah satu contoh yang disebut dengan the future of retailaing (Grewal, Roggeveen, \& Nordfält, 2017)

Untuk saat ini, hanya tiga kecamatan di Batam yang belum dimasuki oleh kedua ritel yang bersangkutan yaitu Kecamatan Belakang Padang, Galang, dan Bulang. Itu artinya, dari 12 kecamatan yang ada di Kota Batam, sembilan kecamatan telah merasakan masing masing ritel tersebut. Kecamatan yang mendominasi adalah kecamatan Sagulung, hal ini masuk akal karena kecamatan ini adalah kecamatan dengan penduduk terpadat, 177.896 jiwa (BPS Batam, 2017). Menyusul Batu Aji, Bengkong, Batam Kota, disusul dengan kecamatan lainnya. Tabel 1.1 berikut memaparkan jumlah masing-masing di setiap kecamatan. Total toko ritel Indomaret sebanyak 140 toko dan total Alfamart sebanyak 147 toko. Cepatnya pertumbuhan jumlah kedua ritel ini di kota Batam, membuat pemerintah memberikan batas atau kuota hingga 150 saja untuk masing-masing ritel karena sudah melampaui jumlah yang sudah diperkirakan sebelumnya.

Maraknya jumlah ritel Indomaret dan Ritel Alfamart di kota Batam menjadi ancaman yang mau tidak mau harus diterima oleh para pemilik ritel tradisional yang sering disebut dengan warung dan toko klontong yang berada di lingkungan perumahan dan di pasar tradisional. Ritel tradisional memiliki karakteristik keadaan fisik baik (ada sebagian yang baik), memiliki modal/subsidi lemah, metode pembayaran ditandai dengan adanya proses tawar menawar, jaringan yang dibangun belum luas atau disebut pasar regional (Utomo, 2011). Persaingan semakin ketat, belum lagi bersaing dengan ritel online yang menjamur dengan pelayanan yang bersifat memanjakan minat konsumen. Salah satu factor pengambilan keputusan beli di ritel modern adalah visual display-nya, tidak ada yang sanggup menolak (Grewal et al., 2017).

Pesatnya pertumbuhan jumlah ritel Indomaret dan Alfamart sejak masuknya di Batam yaitu tahun 2014, sangat fantastis. Tanggapan konsumen di Batam melampaui harapan produsen. Banyaknya jumlah kedua ritel ini tidak hanya sangat mengancam, tapi telah berdampak langsung terhadap usaha kecil menengah. Sejumlah fakta dari hasil survey menunjukkan bahwa telah banyak warung menjadi tutup, bubar, dan tidak beroperasi lagi sama sekali. Kasus ini berlaku di semua komplek perumahan dan di pemukiman kavling. Setiap kehadiran minimarket yang baru akan selalu berdampak (mengurangi/mematikan) pada pasar tradisional maupun minimarket lainnya (Giovanni \& Tadei, 2014).

Kasus ini semakin hari semakin menjadi-jadi, bahkan oleh Wakil Ketua Kadin Kepri dan Dewan Koperasi Kota Batam mengatakan izin buka usaha minimarket tersebut sudah ditutup sejak tahun 2016 lalu tapi hingga tahun 2018 masih ada gerai Indomaret dan Alfamart yang baru buka (http://batamnews.co.id/berita). Kedua ritel ini berdiri hampir selalu berdampingan, tidak peduli apakah berada dilokasi yang dilarang oleh peraturan pemerintah, di 
lokasi yang bisa membunuh usaha lokal, serta dampak buruk lainnya. Minimarket, dalam peraturan perundang-undangan termasuk dalam pengertian "Toko Modern".

Peraturan mengenai toko modern diatur dalam Perpres No. 112 Tahun 2007 tentang Penataan dan Pembinaan Pasar Tradisional, Pusat Perbelanjaan dan Toko Modern (Perpres 112/2007). Pengertian toko modern menurut Pasal 1 angka 5 Perpres 112/2007 adalah toko dengan sistem pelayanan mandiri, menjual berbagai jenis barang secara eceran yang berbentuk Minimarket, Supermarket, Department Store, Hypermarket ataupun grosir yang berbentuk Perkulakan. Setiap toko modern wajib memperhitungkan kondisi sosial ekonomi mayarakat sekitar serta jarak antara toko modern dengan pasar tradisional yang telah ada (Pasal 4 ayat (1) Perpres.

Dari usaha Indomaret dan Alfamart mengalihkan minat konsumen yang paling menarik adalah promosinya. Ritel ini sangat memahami konsumen melalui bauran pemasaran yaitu promosi. Kelengkapan produk, kualitas produk, lokasi yang strategis, kemudahan akses dengan kendaraan, ruang yang bersih, penataan ruang yang rapi, pelayan atau karyawan yang ramah, merupakan faktor lain untuk memikat minat konsumen. Promosi yang rutin akan selalu menarik minat konsumen (Abayi \& Khoshtinat, 2016). Indomaret lihai mengatur diskon secara berkala terhadap tiap produk pada waktu-waktu tertentu, demikian juga dengan perhatian pada service scape sangat memenuhi harapan konsumen. Service scape berpengaruh signifikan terhadap keputusan pembelian (R. Emor, 2015). Publikasi yang cukup terhadap barang yang dijual.

Hasil survey menunjukkan bahwa kehadiran per satu ritel Indomaret atau Alfamart bisa ada ditiap komplek perumahan atau pemukiman. Seiring dengan itu, ada kasus tiga sampai lima warung dan toko kelontong yang sepi pengunjung, sering tutup, dan bubar. Situasi ini bukan hanya berdampak pada warung atau toko melainkan juga membuat minimarket dalam kompetisi antara tipe ritel yang sama disebut intratype competition, mengeluh dan mati. Satu contoh yang sangat tragis adalah di lokasi pertokoan di Kampung Utama, sebuah minimarket hasil usaha beberapa mahasiswa memilih tutup akibat kehadiran Indomaret dan Alfamaret pada tahun 2017. Pedagang kaki lima juga ikut menjerit, berharap segmen konsumen tetapnya seperti anak-anak tetap bertahan. Kasus lain, puluhan kios pedagang makanan ringan yang sudah ada sejak tahun 2000-an di simpang lampu merah menuju Barelang, khusus melayani segmen wisatawan. Wisatawan ini menuju tempat wisata Jembatan Barelang, Kampung Vietnam, pantai, dan tempat diving and snorkeling. Satu persatu tutup, memilih menyerah karena pendapatan dari penjualan makanan ringan untuk hanya sekedar menutupi sewa kios saja, kurang.

Pedagang non minimarket dan convenience store semakin melemah seiring dengan kehadiran ritel modern (Krittanathip, Rakkarn, \& Cha-um, 2013). Dalam penelitian ini, peneliti konsentrasi dengan analisis situasi yang dihadapi oleh toko mom and pop di Batam setelah kehadiran ritel modern khususnya Indomaret dan Alfamart. Dan sejauh mana pengaruh kehadiran Indomaret dan Alfamart mempengaruhi toko dan warung di Kota Batam?

\section{TINJAUAN PUSTAKA}

Ritel modern adalah ritel mencakup semua kegiatan yang terlibat dalam penjualan barang atau jasa secara langsung kepada konsumen akhir untuk penggunaan pribadi bisnis non mereka (Kotler, 2012). Ritel tradisional merupakan pandangan yang menekankan pengelolaan ritel dengan mengunakan pendekatan konvensional dan tradisioanal. (Utami, 2017). Menurut Sinaga (2006), ritel tradisional adalah ritel yang berupa kios atau warung rumah tangga yang dikelola dengan manjemen lebih tradisional dan pada umumnya berada di sekitar lingkungan perumahan.

Dalam manajemen pemasaran, ritel tradisional merupakan sebutan lain dari mom and pop store atau toko mom and pop. Operasi "mom dan pop" secara tradisional menjadi sumber penting pertumbuhan bisnis kecil. Membangun bisnis di dalam keluarga, mengumpulkan modal dari dalam keluarga dan menginvestasikan kembali modal dalam infrastruktur bisnis menciptakan peluang untuk pertumbuhan yang solid, paparan risiko yang terbatas, dan tenaga kerja yang setia dan berdedikasi. Memang, bisnis "mom and pop" sudah mulai berubah. Dalam bidang-bidang seperti penulisan lepas, grafik, dokumen real estat, penjadwalan, dan bahkan 
target pemasaran, bisnis "mom and pop" semakin menangkap sebagian dari outsourcing bisnis internasional, dengan perputaran biaya rendah, teknologi biaya rendah dan infrastruktur komunikasi "tanpa biaya".

Bauran ritel adalah elemen-elemen yang menjadi faktor penentu dalam implementasi strategi dan taktik yang dijalankan oleh peritel termasuk ritel Indomaret dan Alfamart. Bauran ritel terdiri dari beberapa elemen yaitu Place, People, Product, Price, Promotion. Kelima elemen tersebut saling melengkapi satu dengan lainnya sehingga digambarkan dalam wujud bangunan menyerupai rumah (Utami, 2017).

Pertama, lokasi adalah faktor yang sangat penting dalam bauran ritel. Pada lokasi yang tepat, sebuah gerai akan lebih sukses dibandingkan gerai lainnya yang berlokasi kurang strategis, meskipun keduanya menjual produk yang sama, merchandise dijual oleh pramuniaga yang sama banyak dan sama-sama memiliki keterampilan, bahkan sama-sama memiliki setting /ambience yang bagus. Ritel mempunyai 3 tipe dasar lokasi yang bisa dipilih; Pusat perbelanjaan, lokasi di kota besar atau bertempat di tengah kota, maupun kota kecil, dan freestanding (bebas).

Kedua adalah produk, produk yang dijual peritel dalam gerainya, disebut merchandise merupakan satu dari unsur bauran pemasaran ritel (retail marketing mix). Produk yang dibeli oleh peritel untuk dijual kembali merupakan penerjemahan dari positioning yang dipilih oleh peritel tersebut (karena penting bagi peritel untuk menentukan positioining di awal memulai bisnis). Merchandise yang akan dijual penting untuk dipilih dengan karena merchandise adalah mesin sukses bagi pengecer.

Ketiga Harga (Price), keputusan penetapan harga semakin peting karena pelanggan saat ini cenderung mencari nilai barang (value) ketika mereka membeli barang dagangan atau jasa. Nilai adalah hubungan antara apa yang diperoleh pelanggan (barang dan jasa) dan dan apa yang harus dia bayar untuk mendapatkan manfaat barang tersebut. Seringkali penetapan harga yang dilakukan oleh ritel skala besar yang menyediakan item barang dagangan sampai puluhan ribu merupakan hal yang biasa, sedangkan bagi ritel yang baru memulai usaha dan belum memiliki sistem ataupun tenaga trampil dalam menetapkan harga, maka satu-satunya langkah yang dapat dilakukan adalah membenahi dan membangun sistem pengadaan barang dagangan yang baik dengan tidak meninggalkan keinginan untuk membangun relasi yang baik dan saling menguntungkan dengan pihak pemasok dan didukung pula oleh keberadaan sistem informasi yang handal dan canggih.

Keempat adalah Orang (People) Manajemen Sumber Daya Manusia dapat menjadi dasar untuk mendapatkan keuntungan yang kompetitif, dengan tiga alasan sebagai berikut. Pengelolaan Sumber Daya Manusia yang baik akan mewujudkan kinerja operasional karyawan ritel yang baik pula dan dapat mewujudkan keuntungan potensial bagi ritel. Keuntungan potensial tersebut sulit atau bahkan tidak dapat ditiru oleh pesaing. Contoh, tiap eksekutif departemen toko memahami tentang pentingnya penyediaan layanan bagi pelanggan yang dilakukan oleh karyawan dalam menyambut pelanggan secara outstanding (karyawan berdiri di luar toko), namun tiap eksekutif tidak mungkin secara terus menerus melakukan pengawasan agar standar pelayanan ini konsisten dilaksanakan. Hal ini akan sangat tergantung pada komitmen masing-masing pekerja ritel dan sangat berorientasi pada budaya perusahaan tersebut.

Kelima adalah promosi (Promotion), bisnis ritel berkaitan dengan pemasaran barangbarang (atau jasa) yang dibutuhkan perorangan dan rumah tangga. Pembahasan mengenai konsumen berarti berbicara tentang pikiran dan emosi mereka. Dengan demikian image atau citra perusahaan ritel yang ingin diciptakan dapat berwujud dalam bentuk; image secara umum, atribut merchandise, dll. Jika digabungkan image secara lengkap akan berbunyi" sebagai 3 besar peritel nasional yang menyajikan produk lengkap dan bermutu dengan harga wajar di gerai yang ditata secara nyaman di lokasi prima dengan pelayanan prauniaga yang sopan dan terlatih dan akarb dengan lingkungan. Image akan dibangun dengan program promosi.

Melakukan kegiatan usahanya di lokasi yang nyaman dan mudah diakses pelanggan. Memberikan beragam produk sehingga memungkinkan pelanggan bisa memilih produk yang diinginkan. Membagi jumlah produk yang besar sehingga dapat dijual dalam kemasan/ukuran 
yang kecil. Mengubah produk menjadi bentuk yang lebih menarik. Menyimpan produk agar tetap tersedia pada harga yang relatif tetap. Membantu terjadinya perubahan (perpindahan) kepemilikan barang dari produsen ke konsumen. Mengakibatkan perpindahan barang melalui sistem distribusi. Memberikan informasi, tidak hanya ke pelanggan, tapi juga ke pemasok. Memberikan jaminan produk layanan purna jual, dan turut menangani keluhan pelanggan. Dan memberikan fasilitas kredit dan sewa.

Usaha ritel memberikan kebutuhan ekonomis bagi pelanggan melalui lima cara: Memberikan suplai/pasokan barang dan jasa pada saat dan ketika dibutuhkan konsumen/pelanggan dengan sedikit atau tanpa penundaan. Memudahkan konsumen/pelanggan dalam memilih atau membandingkan bentuk, kualitas dan barang serta jasa yang ditawarkan. Menjaga harga jual tetap rendah agar mampu bersaing dalam memuaskan pelanggan. Membantu meningkatkan standar hidup masyarakat. Adanya usaha ritel juga memungkinkan dilakukannya produksi besar-besaran (produksi massal).

Indomaret dan Alfamart merupakan toko modern yang menjual berbagai macam barang-barang yang dibutuhkan oleh konsumen. Alfamart menjual berbagai produk dan jasa kepada para konsumen untuk keperluan konsumsi pribadi, tetapi bukan untuk keperluan bisnis dengan memberikan upaya terhadap penambahan nilai barang dan jasa tersebut. Alfamart dan Indomart mencoba untuk memuaskan kebutuhan-kebutuhan konsumen dengan mencoba memenuhi kesesuaian barang-barang yang dimilikinya, pada harga, tempat, dan waktu yang diinginkan pelanggan. Indomart saling bersaing dengan Alfamart dalam menarik minat konsumen untuk belanja di tokonya. Indomart memberikan pelayanan yang serupa dengan Alfamart mulai dari cara melayani konsumen, fasilitas-fasilitas yang diberikan, jenis-jenis produk serta kualitas dan kuantitas produk.

\section{METODE}

Jenis penelitian ini adalah penelitian kualitatif dengan pendekatan studi kasus jenis analisis situasi. Jenis studi kasus penelitian ini adalah mencoba menganalisis situasi terhadap peristiwa atau kejadian tertentu. Analisis situasi eksternal merupakan tinjauan ulang secara sistematis latar belakang masalah yang berada di luar organisasi. Jenis dari analisis situasi eksternal mencakup data sekunder (studi pustaka), survei, pengamatan, dan analisis isi. Jenis data yang akan dikumpulkan dalam penelitian ini adalah data kualitatif, yang berasal dari sumber data tertulis dan tidak tertulis. Mengambil beragam sumber informasi dnegan melakukan pengamatan langsung, wawancara, dan dokumen. Adapun teknik pengumpulan data yang digunakan dalam penelitian ini adalah:

1. Observasi (Pengamatan)

Dalam teknik ini peneliti menggunakan teknik observasi lansung dengan membuat kunjungan lapangan terhadap kasus, dimana peneliti menciptakan kesempatan untuk observasi lansung ke lokasi perumahan, pemukiman (Kavling), pasar tradisional, toko klontong, dan warung. Dengan maksud melakukan pengamatan dan pencatatan secara sistematis untuk memahami gejala yang diselidiki atau diamati.Pengamatan langsung dilakukan peneliti pada saat jam proses beroperasinya (jual beli). Dalam kurun waktu tersebut, peneliti mengamati satu tahun, tahun 2017. Observasi dilakukan untuk menggambarkan bagaimana proses masuknya (buka) Indomaret dan Alfamart di lokasi perumahan, pemukiman, dan pasasr tradisional. Hasil pengamatan tersebut semuanya di catat dalam lembar catatan lapangan dan dibantu dengan daftar cek. Catatan lapangan berupa laporan sebelum dan sesudah masuknya (buka) Indomaret atau Alfamart atau dua duanya sekaligus. Selanjutnya dikembangkan oleh peneliti sesudah pengamatan dilakukan serta memberikan tanggapan sebagai bentuk refleksi dari hasil pengamatan tersebut. Kemudian daftar cek, diisi oleh peneliti untuk mengingatkan peneliti apakah seluruh aspek informasi sudah dijaring atau belum. Melalui pengamatan langsung diharapkan memperoleh temuan mendetail tentang peristiwa yang berkaitan dengan masalah penelitian.

2. Interview (Wawancara) 
Interview (wawancara) merupakan salah satu teknik pengumpulan data yang dilakukan dengan cara mengadakan tanya jawab baik secara langsung maupun tidak langsung. Dengan teknik ini penulis memilih wawancara bertipe open-ended, dimana peneliti dapat bertanya kepada informan kunci tentang fakta-fakta suatu peristiwa disamping opini mereka tentang pristiwa tersebut. Wawancara ditujukan kepada 5 (lima) pihak, Indomaret, Alfamart, Pemilik minimarket, toko klontong, dan warung. Dalam pelaksanaan wawancara, peneliti hanya mencatat hal-hal pokok atau kata-kata kunci dari jawaban informan dalam buku catatan. Kemudian setelah proses wawancara selesai, peneliti mendeskripsikan hasil wawancara ke dalam lembar catatan dengan format catatan lapangan. Setelah catatan lapangan selesai dibuat, peneliti memahami dan memberikan tanggapan pada lembar refleksi. Refleksi dimaksudkan untuk mengklarifikasi data-data yang diragukan dan membingungkan yang ada catatan lapangan.

3. Dokumentasi

Dalam penelitian ini, dokumen yang akan dijadikan data pendukung dari hasil observasi dan wawancara adalah dokumen resmi. Dokumen yang dijadikan sumber dalam penelitian ini adalah photo. Setelah data-data terkumpul melalui observasi, wawancara dan analisis dokumen, maka selanjutnya menganalisis data-data tersebut. Adapun teknik analisis yang digunakan adalah teknik analisis deskriptif, yang dilakukan melalui tiga alur kegiatan. yaitu: reduksi data, penyajian data dan penarikan kesimpilan atau verifikasi. Dimana tiga janis kegiatan tersebut merupakan proses siklus dan interaktif. Langkah analisis interaktif terdiri atas beberapa komponen kegiatan yang terkait satu sama lain, dimulai dari pengumpulan data kemudian mereduksi data, penyajian data dan penarikan kesimpulan/verifikasi. Untuk lebih jelasnya, penulis menggambarkan sebagai berikut:

1. Reduksi data

Reduksi data merupakan proses menyeleksi, menentukan fokus, menyederhanakan, meringkas dan mengubah bentuk data yang ada dalam catatan lapangan.

2. Penyajian data

Setelah data direduksi, langkah analisis selanjutnya adalah penyajian (display) data. Penyajian data diarahkan agar data hasil reduksi terorganisasikan, tersusun secara sistematis yang memberikan kemungkinan adanya penarikan kesimpulan dan pengambilan tindakan. Dalam langkah ini penulis menyajikan data dalam bentuk teks naratif. Teks itu muncul dalam bentuk catatan lapangan tertulis, yang disaring oleh peneliti dengan mengutip penggalan-penggalan berkode dan menarik kesimpulan. Penyajian data dalam bentuk teks naratif tersebut akan memudahkan peneliti untuk memahami data-data penelitian. Selanjutnya peneliti menyusun data-data yang relevan sebagai sekumpulan informasi tersusun yang memberi kemungkinan adanya penarikan kesimpulan dan pengambilan tindakan sehingga menjadi informasi yang dapat disimpulkan. Adapun langkahnya dilakukan dengan cara menarasikan data secara sistematis untuk memaknai apa yang sebenarnya terjadi dan apa yang perlu ditindak lanjuti untuk mencapai tujuan penelitian, hal ini dilakukan sebagai upaya atau langkah penting menuju tercapainya analisis.

\section{HASIL DAN PEMBAHASAN}

Total jumlah toko ritel Indomaret dan Alfamart di Batam hingga tahun 2018 sebanyak 140 toko Indomaret dan sebanyak 147 toko Alfamart. Cepatnya pertumbuhan jumlah kedua ritel ini di kota Batam, membuat pemerintah memberikan batas atau kuota hingga 150 saja untuk masingmasing ritel karena sudah melampaui jumlah yang sudah diperkirakan sebelumnya. Untuk mempermudah penjabaran analisis situasi mulai dari permasalahan, proses perumusan dan analisis hasil, maka langkah langkah singkat terdiri dari: 


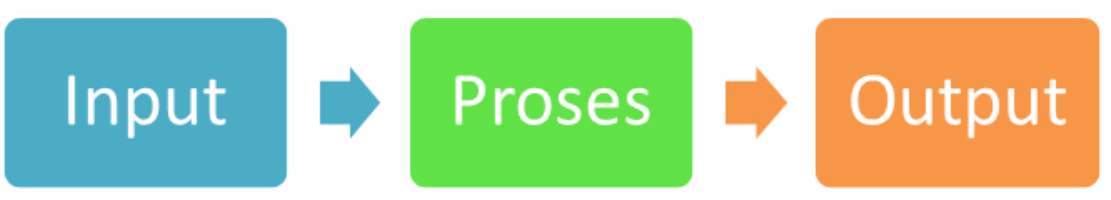

Ritel Indomaret dan Alfamart adalah jenis ritel yang termasuk jenis jaringan minimarket. Ratusan toko Indomaret dan Alfamart berdiri di Sembilan kecamatan dari 12 kecamatan yang ada di Kota Batam. Dua kecamatan diantaranya menjadi sorotan dalam penelitian ini yaitu Kecamatan Batu Aji dan Kecamatan Sagulung. Kecamatan Sagulung dengan jumlah penduduk 177.896 jiwa (BPS Batam, 2017) dan Kecamatan Batu aji dengan jumlah penduduk 127.406 jiwa (BPS Batam, 2018). Jadi tidak heran kalau kehadiran Indomaret dan Alfamart lebih banyak di dua kecamatan ini. Di Kecamatan Sagulung terdapat 19 toko Indomaret dan 20 Toko Alfamart. Di kecamatan Batu Aji sebanyak 20 toko Indomaret dan 9 toko Alfamart.

Lokasi penelitian dari dua kecamatan ini adalah Simpang Lampu merah kearah Barelang dan lokasi Fanindo. Dalam tahap ini, mengumpulkan data dari hasil observasi, wawancara dan dokumentasi dengan satu toko klontong di tiap komplek perumahan atau kavling, tiga pemilik warung yang sudah tutup/bubar, dua pemilik warung yang masih buka/jualan, pedagang-pedagang ke arah salah satu tempat wisata, karyawan Indomaret dan Alfamart yang sudah berkerja lebih dari satu tahun.

Tabel 1

\begin{tabular}{ll}
\hline Di Kecamatan Sagulung & Kecamatan Batu Aji \\
\hline Perumahan Citra Laguna 1, 2, dan 3 & Perumahan Putri Tujuh \\
Perumahan Cipta Asri & 2. Perumahan Griya Pratama \\
Perumahan Buana Impian & 3. Perumahan Griya Prima \\
Pasar SP (Sentosa Plaza) & 4. Pasar Aviari \\
Area Pedagang Simpang Barelang & 5. Area Pedangang Simpang Base Camp \\
\hline
\end{tabular}

Di Kecamatan Sagulung, dari lokasi yang sudah ditentukan selanjutnya ditetapkan jumlah warung dan toko kelontong serta area pedagang seperti yang tertera pada tabel dibawah ini. Sesuia dengan permintaan para pemilik warung dan kelontong, nama dan identitas lainnya tidak diijinkan untuk dipublikasikan kecuali dokumentasi dalam bentuk photo.

Nama-nama lokasi perumahan yang dipilih berdasarkan jumlah perumahan terbanyak dan jumlah penduduk terpadat. Di kecamatan Sagulung dipilih perumahan Citra Laguna Tahap 1, 2, dan 3, Perumahan Cipta Asri, Perumahan Buana Impian, Pasar SP, dan Para pedagang di Simpang Barelang. Sementara di Kecamatan Batu Aji, dipilih perumahan Putri Tujuh, Perumahan Griya Prima, Perumahan Griya Pratama, Pasar Aviari, dan Para pedagang di Simpang Base Camp.

Baik itu Indomaret maupun Alfamart, tidak memiliki perbedaan yang ketara dalam hal jenis produk dan layanan yang diperjualbelikan. Jenis barang yang dijual adalah toiletis (sabun mandi, deterjen, pasta gigi, pelembut, sabun cuci, pembersih kamar mandi dll.), kosmetik (bedak, parfum, tisu, kapas, pembalut, dll.) dan kebutuhan pokok. Lebih jelasnya ada pada table berikut.

Tabel 2

No Variabel Kategori Keterangan




\begin{tabular}{|c|c|c|c|}
\hline \multirow[b]{2}{*}{1} & & Food & $\begin{array}{l}\text { Snack, coklat, minyak goreng, minuman, es } \\
\text { krim, biscuit, buah, bumbu masak, roti, mie } \\
\text { instan, telur, rokok, susu, dan lainnya. }\end{array}$ \\
\hline & Produk & Non food & $\begin{array}{l}\text { Detergen, pasta gigi, sikat gigi, sabun } \\
\text { mandi, parfum, kosmetik, baby \& kids care, } \\
\text { alat tulis, obat-obatan, alat kebersihan, dan } \\
\text { lainnya. }\end{array}$ \\
\hline \multirow{2}{*}{2} & Pelavanan & $\begin{array}{ll}\text { SOP } & \text { (Standart } \\
\text { Opersional } & \\
\text { Prosedure) } & \end{array}$ & $\begin{array}{l}\text { Salam sapa " selamat datang dan selamat } \\
\text { berbelanja" dan mengucapkan "terima } \\
\text { kasih silahkan belanja kembali" ketika } \\
\text { pelanggan selesai berbelanja }\end{array}$ \\
\hline & & Fasilitas & Keranjang belanja, AC dan mesin ATM \\
\hline
\end{tabular}

Hal yang sama dengan produk yang diperjualbelikan di warung dan toko klontong. Unsur layanan dan fasilitas yang membedakan. Dalam penelitian ini murni membicarakan penjualan barang seeprti yang tertera pada table diatas. Untuk produk I-Tiket, I-Payment, Token, T-Cash, Rekening Ponsel, ATM Indomaret, dan lain lain, tidak termasuk dalam penelitian karena tidak berpengaruh signifikan dengan kondisi yang dialami oleh pemilik warung dan toko kelongtong.

\section{PEMBAHASAN}

Berikut ini bentuk wawancara terstruktur dengan para pedagang mom and pop (sumber informasi). Setiap pertanyaan yang sama pada waktu yang berbeda ditanyakan kepada sumber informasi. Lokasi sumber informasi ditentukan secara merata di penjuru Kota Batam , mengingat keberadaan ritel modern juga memasuki semua wilayah geografis.

1. Wawancara dengan pemilik warung dan toko kelontong yang sudah bubar:

(Sudah berapa lama toko berdiri? Jenis produk yang dijual (Sembako dan barang basah; sayur dan ikan)? Sudah berapa lama tidak lagi beroperasi (jualan)? Mengapa tidak lagi jualan (mengapa bubar/tutup)?

2. Wawancara dengan pemilik warung dan toko kelontong yang masih beroperasi: Sudah berapa lama toko berdiri? Jenis produk yang dijual (Sembako dan pasar basah; sayur dan ikan)? Perubahan apa yang terjadi sejak adanya Indomaret atau Alfamart disekitar? Langkah selanjutnya, terus bertahan atau bubar?

3. Wawancara dengan pedagang di area menuju kawasan wisata Barelang dan Simpang Base Camp Pedagang yang tidak lagi jualan: Sudah berapa lama toko berdiri/jualan? Jenis produk yang dijual apa saja? Sudah berapa lama tidak lagi beroperasi (jualan)? Mengapa tidak lagi jualan (mengapa bubar/tutup)?

4. Wawancara dengan pedagang di area menuju kawasan wisata Barelang dan Simpang Base Camp (pedangang yang masih jualan): Sudah berapa lama berdiri/jualan? Jenis produk yang dijual ? Perubahan apa yang terjadi sejak adanya Indomaret atau Alfamart disekitar? Langkah selanjutnya, terus bertahan atau bubar?

Setelah dilakukan wawancara langsung dengan pemilik warung, baik itu warung yang sudah bubar maupun masih beroperasi maka diperoleh hasil wawancara sebagai berikut:

1. Wawancara dengan pemilik warung dan toko kelontong yang sudah bubar: Toko berdiri rata-rata sudah sejak 3 sampai 10 tahun. Jenis produk yang dijual kebanyakan toko menjual sembako. Akibat kehadiran ritel modern, too tidak lagi beroperasi pada kisaran waktu 1 sampai 4 tahun. Alasan tidak lagi jualan karena kalah saing dengan toko toko modern yang sangat menawan.

2. Wawancara dengan pemilik warung dan toko kelontong yang masih beroperasi: Toko berdiri rata-rata sudah sejak 5 sampai 12 tahun. Jenis produk yang dijual kebanyakan 
toko menjual barang basah plus sembako. Perubahan yang terjadi sejak adanya Indomaret atau Alfamart mengakibatkan berkurangnya pembeli sembako tapi tidak dengan barang basah. Langkah selanjutnya adalah mencoba tetap bertahan.

3. Wawancara dengan pedagang di area menuju kawasan wisata Barelang dan Simpang Base Camp Pedagang yang tidak lagi jualan: Berapa lama toko berdiri/jualan? Ratarata sudah diatas 10 tahun. Jenis produk yang dijual adalah makanan ringan dan minuman ringan. Lamanya tidak lagi beroperasi (jualan) berkisan Antara 3 sampai 5 tahun. Alasan tidak lagi jualan (mengapa bubar/tutup) adalah karena kalah bersaing.

4. Wawancara dengan pedagang di area menuju kawasan wisata Barelang dan Simpang Base Camp (pedangang yang masih jualan): Sudah berapa lama berdiri/jualan? Jenis produk yang dijual ? Perubahan apa yang terjadi sejak adanya Indomaret atau Alfamart disekitar? Langkah selanjutnya, terus bertahan atau bubar?

\section{SIMPULAN}

Permasalahan yang dihadapi oleh jenis mom and pop store di Batam hingga tahun 2018 bukanlah permasalahan yang ringan. Ritel modern yang bermunculan dan menjamur di secara merata di komplek perumahan dan lokasi pasar menjadi ancaman berat bagi para pemilik toko mom and pop. Kehadiran ritel modern ini tidak bisa ditolak dan dilawan oleh mereka yang berkepentingan langsung karena akses melalui pemerintah kota terbuka luas. Akibatnya berjumlah ratusan ritel modern khususnya ritel Indomaret dan ritel Alfamart telah berdiri di kota Batam. Toko mom and pop menjadi tersingkirkan, berkisar antara 4 sampai lima toko mom and pop yang bubar dan tutup di setiap komplek perumahan. Harapan bagi para pemilik toko mom and pop yang masih bertahan hingga sekarang adalah campur tangan pemerintah untuk batasan kuota terhadap jumlah ritel modern. Juga keterlibatan pemerintah baik secara finansial maupun pemikiran untuk membina masyarakat akan cara bersaing untuk tetap bertahan di pasaran.

\section{DAFTAR PUSTAKA}

Abayi, M., \& Khoshtinat, B. (2016). Study of the Impact of Advertising on Online Shopping Tendency for Airline Tickets by Considering Motivational Factors and Emotional Factors. Procedia Economics and Finance, 36(16), 532-539. https://doi.org/10.1016/S22125671(16)30065-X

Giovanni, L. De, \& Tadei, R. (2014). Modeling the Retail System Competition. Procedia Social and Behavioral Sciences, 108, 285-295. https://doi.org/10.1016/j.sbspro.2013.12.838

Grewal, D., Roggeveen, A. L., \& Nordfält, J. (2017). The Future of Retailing \&. Journal of Retailing, 93(1), 1-6. https://doi.org/10.1016/j.jretai.2016.12.008

Krittanathip, V., Rakkarn, S., \& Cha-um, S. (2013). Development of Weighting on Selfassessment Evaluation for Total Quality Management: A Case Study of Retail Sectors. Procedia-Social and Behavioral Sciences, 88, 37-48. https://doi.org/10.1016/j.sbspro.2013.08.479

R. Emor, A. S. (2015). Pengaruh potongan harga, citra merek, dan servicescape terhadap keputusan pembelian konsumen indomaret tanjung batu. EMBA, 3(2), 738-748.

Singh, R. S. (2014). India' s Service Sector - Shaping Future of Indian Retail Industry. Procedia Economics and Finance, 11(14), 314-322. https://doi.org/10.1016/S22125671(14)00199-3

Utami, C. W. (2017). Manejemen Ritel.

Kotler, Philip dan Armstrong, Gary. 2012. Principles of Marketing. New Jersey: Prentice Hall. 